\title{
İngiltere Yerel Yönetim Ombudsmanlı̆̆ının Etkinliği Üzerine Bir Değerlendirme
}

\author{
DOI: 10.26466/opus.808839
}

*

Melike Erdoğan *

* Dr. Öğr. Üyesi, Çanakkale Onsekiz Mart Üniversitesi, Siyasal Bilgiler Fakültesi, Siyaset Bilimi ve Kamu Yönetimi Bölümü

E-Posta: melike.erdogan@comu.edu.tr

ORCID: $\quad \underline{0000-0001-6822-7445}$

\section{Öz}

Devlet ile vatandaş arasındaki ilişkilerde bireysel hakların korunmasında denetim önemlidir. Denetimin etkin olabilmesine yönelik bağımsız ve tarafsız ombudsmanlık kurumu oluşturulmuştur. Yerel yönetimlerin denetiminde etkinliğin sağlanması ve görevlerinin artması nedeniyle yerel yönetimlere yönelik görev yapacak yerel yönetim ombudsmanlıklarının kurulması ihtiyacı ortaya çıkmıştır. Yerel yönetim ombudsmanliğı yerel yönetimlerle vatandaş arasındaki ilişkilerde ortaya çıkan şikayetleri incelemekte ve çözüm önerileri sunmaktadır. Yerel yönetim ombudsmanlığı uygulaması ilk olarak 1974 yılında İngiltere'de ortaya çıkmış olup, daha sonra farklı ülkelerde de uygulanmaya başlamıştır. Bu çalışmada da yerel yönetim ombudsmanlığının ilk örneği olan İngiltere yerel yönetim ombudsmanlı̆̆ının yapısı, işleyişi ve faaliyetleri incelenmiştir. Çalışmanın amacl; verilen hizmetlerden vatandaşların memnuniyeti ve mali açılardan Ingiltere yerel yönetim ombudsmanlı̆̆ının etkinliğini ortaya koymaktır. Çalışma İngiltere Yerel Yönetim Ombudsmanlığg'nın 2013- 2019 yılları arasındaki yıllık raporları ve müşteri memnuniyeti anketleri dokümanlarının incelenmesi yöntemi ile gerçekleştirilmiştir. Çalışma sonucunda vatandaşların şikayetlerin değerlendirme süresi ile verilen kararlardan memnun olmadığı, kurumun personel ve mali kaynak açısından desteklenmesi gerektiği sonucuna ulaşılmıştır.

Anahtar Kelimeler: Ombudsman, İngiltere, Yerel Yönetim Ombudsmanlı̆̆l, Etkinlik, Denetim. 


\title{
An Evaluation About Effectiveness of England Local Government Ombudsman
}

\begin{abstract}
The audit is important in the protection of individual rights in the relations between the state and the citizen. An independent and impartial ombudsman institution has been established for the effectiveness of the audit. The need to establish local government institutions has emerged due to the supervision of local governments and the increase in their duties. The local government ombudsman analyzes the complaints arising in the relations between local governments and the citizen. The local government ombudsman first was established in England and then it was started to open in different countries. The structure and functions of the England Local Government Ombudsman, which is the first example of a local government ombudsman, are examined in this study. The aim of this study is to demonstrate the effectiveness of the England Local Government Ombudsman in terms of citizen satisfaction of providing the services and financial The study was carried out by examining the documents of the England Local Government Ombudsman's annual reports and customer satisfaction surveys between 2013-2019. As a result of the study, it was concluded that the citizens were dissatisfied with the evaluation period of the complaints and the decisions and, the institution should be supported in terms of personnel and resource.
\end{abstract}

Keywords: Ombudsman, England, Local Government Ombudsman, Effectiveness, Audit. 


\section{Giriş}

Yönetilenlerin hakların korunması için kamu yönetimi farklı şekillerde denetlenmektedir. Kamu yönetiminin denetlenmesinde idari denetim, yargı denetimi ve yargı dışı denetim söz konusudur. Yargı dışı denetim yolu olarak 18. yüzyılda İsveç'te ombudsmanlık kurumunun temeli atılmıştır. Ombudsmanlık idare ile vatandaş arasındaki ilişkilerden doğan şikayetleri inceleyen ve arabuluculuk yapan bir kurumdur. İsveç Ombudsmanlığının başarılı uygulamaları başta İskandinav ülkeleri olmak üzere diğer ülkelerde de ombudsmanlık kurumunun oluşturulmasını sağlamıştır.

Devletler kendi ülkelerinin koşullarına ve ihtiyaçlarına göre farklı alanlara özgü ombudsmanlıklar oluşturmaya başlamıştır. Bunlardan biri de; hizmet sunduğu alanda yetkisi sınırlı olan yerel yönetimler ve yerel halk arasındaki ilişkilerden doğan şikayetleri inceleyen yerel yönetim ombudsmanlı̆̆ıdır. Yerel yönetim ombudsmanlığı ilk olarak 1974 yılında İngiltere'de kurulmuştur.

Bu çalışmanın konusu ilk örnek olan İngiltere Yerel Yönetimler Ombudsmanlığı'nın yapısı, işleyişi ve faaliyetlerini incelemektir. Çalışmanın amacı; İngiltere Yerel Yönetimler Ombudsmanlığı'nın etkinliğinin değerlendirilmesidir. Çalışma üç bölümden oluşmaktadır. Çalışmanın ilk bölümünde ombudsman ve yerel yönetimler ombudsmanlığı kavramları açiklanacaktır. İkinci bölümde İngiltere Yerel Yönetimler Ombudsmanlığı'nın kuruluş süreci, yapısı ve işleyişi hakkında bilgi verilecektir. Çalışmanın son bölümünde ise; 2013-2019 yılları arasındaki yıllık raporlar ve müşteri memnuniyeti anketlerindeki verilerden elde edilen bulgular değerlendirilecektir.

\section{Ombudsman Kavramı}

İsveç'çe bir kelime olan ombudsman temsilci, sözcü anlamına gelen ombuds ve kişi anlamına gelen man kelimelerinden meydana gelen birleşik bir kelimedir. İsveç dilinde halkın koruyucusu ve çıarlarının savunucusu olarak açıklanmaktadır (Parlak ve Doğan, 2019, s.78). Ombudsmanlık kurumunun ilk temeli İsveç'te atılmıştır. 18.yüzyılda İsveç kralı tarafından düzensizlik ve kargaşa ortamına karşı yasalara uyulmasını sağlamak ve kamu görevlilerinin yükümlülüklerini yerine getirebilmesi için oluşturulmuştur. Kurumun 
dünya genelinde yaygınlaşması 20. yüzyılda gerçekleşmiştir (Sezen, 2001, s.73).

İsveç ombudsmanlık uygulamasının Osmanlı Devleti'ndeki şeyhülislamlık kurumundan esinlenerek oluşturulduğu öne sürülmektedir. 1709 yılında Ruslara yenilen İsveç Kralı Demirbaş Şarl Osmanlı Devleti'ne sığınarak, 5 yıl Osmanlı topraklarında kalır. Ülkesini uzaktan yönetmek için bu süreçte bir ferman yayınlayarak bir ombudsman bürosu oluşturur. Ombudsmanlık 1809 yılında İsveç Anayasası ile düzenlenir (Eryılmaz, 2014, s.390). İsveç'te ombudsmanın yasama organı adına yürütme organını ve tüm kamu kurumlarında çalışanları denetleyerek demokrasinin gelişmesine katkıda bulunacağ esası hakim olmuştur (Baylan,1978, s.7).

İsveç'ten sonra benzer şekilde 1920'de Finlandiya'da ombudsmanlık kurumu oluşturulmuştur. 1955'de Danimarka, 1962'de Norveç'te, 1970'li yıllarda Yeni Zelenda, Kanada ve Avustralya'da ombudsmanlık kurulmuştur (Parliamentary Ombudsman of Finland, 2020). Şu anda Uluslararası Ombudsman Kurumu (IOI) verilerine göre dünya genelinde 100'den fazla ülkede 198'den fazla ombudsmanlık kurumu bulunmaktadır (International Ombudsman Institue, 2020).

Ombusdman kavramının üzerinde anlaşılan net ve tek bir tanımı bulunmamaktadır. Tufan Erhürman (1998,s.89) tarafından ombudsman "idarenin eylemleri, işlemleri ve davranışlarn üzerinde hukuka aykırllk ve yerindelik denetimi yapmaya ve hukuka aykır bulduğu veya yerinde bulmadığ işlemleri geri alınması/kaldırlması veya bu işlem veya eylemlerden doğan zararların giderilmesi için ve yurttaşlara yönelik uygunsuz davranışların düzeltilmesi için idare nezdinde girişimlerde bulunmaya ve bağlayıcı olmayan kararlar almaya yetkili olan bağımsız devlet organı" olarak tanımlanmaktadır.

Seriye Sezen (2001, s.72) tarafından ombudsman "yönetimin eylem ve işlemleri hakkında halkı yakınmalarm kabul eden ve bunları sonuçlandıran, araştırma, inceleme ve düzeltici önerilerde bulunma ve bulgularım açılama yetkisi olan kişi ve kurumlar" olarak açıklanmaktadır.

Hasan Tansin Fendoğlu (2017, s.15-16) tarafından ombudsman daha detaylı olarak şu şekilde tanımlanmaktadır: "Yönetimin mağdur ettiği kişilerin şikayeti üzerine harekete geçen, hızh, güvenli bir şekilde araştırma yetkisi ile donatılmış, yapılan haksızlıklar ortaya koymak, takdir yetkisinin kötüye kullanmasını engellemek, mevzuata saygilı olmayı ve uygun hareket etmeyi temin etmek, hakkaniyet 
önlemlerini salı vermek ve nihayet kamu hizmetlerinin daha iyi görülmesi için gerekli reformları yapmak ve öneride bulunmak amaçların güden yetkin, tarafsız, atanmış veya seçilmiş bir kamu görevlisidir." Bu tanımlamalar çerçevesinde ombudsmanı idare ile yönetilenler arasındaki sorunlarla ilgili şikayetleri çözmeye çalışan, tavsiye niteliğinde kararlar alan bir yargı dışı denetim aracı olarak açıklamak mümkündür.

Ombudsmanlık kurumunu ülkeler siyasal kültür, hukuk ve yönetim geleneklerindeki farklılıklara bağlı olarak farklı adlarla oluşturmuşlardır. İsveç ve Finlandiya'da Parlamento Ombudsmanı, Hollanda'da Ulusal Ombudsman, Fransa' da Arabulucu, Kanada'da Vatandaş Koruyucu, İspanya'da Halk Savunucusu, İngiltere'de Yönetim İçin Parlamento Komiseri, İtalya'da Sivil Savunucu ve Türkiye'de Kamu Denetçiliği olarak isimlendirilmektedir (Parlak ve Doğan, 2019, s.104).

Farklı kavramlarla isimlendirilmiş olmasına rağmen ombudsmanlık kurumunun taşıması gereken ortak özellikler bulunmaktadır. Bu özellikleri aşağıdaki gibi açılayabiliriz (Özden, 2010, ss.36-37):

- Ombudsman yasama organı tarafından kurulmaktadır. Ancak yasamadan bağımsız olup, yasama organına karşı çok sınırlı bir sorumluluğu bulunur.

- Yürütme organının ombudsmanlık kurumu üzerinde kontrol yetkisi yoktur.

- Yönetsel sorunları anında çözüme kavuşturabilmesi için kamu belgelerine sınırsız erişim hakkına sahiptir.

- Vatandaşların alınan karara saygi göstermesi ve kabullenebilmesi için kararlarını açıklarken titizlikle davranır.

Ombudsmanın üç temel görevi bulunmaktadır. Öncelikle devletin haksız uygulamalarına karşı vatandaşı koruma görevini yerine getirir. Şikayet konusuyla ilgili araştırma inceleme görevini yapar. Yönetimdeki uygulama hatalarını bularak, yönetimin gelişmesine katkıda bulunmaktadır (Özden, 2010, s.43). Ombudsman kurumunun rolü zaman içerisinde dönüşüme uğramıştır. Denetleyici ve yanlışları düzeltici rolüne uzlaştıııcı, bilgi sağlayıcı, kamu hizmetlerini hızlandırıcı, kamu politikası sürecine katkı sağlayıcı ve tavsiye edici işlevleri de eklenmiştir (Sobacı ve Köseoğlu, 2016, s.107).

Ombudsmanlık tanımlarındaki ortak noktalar çerçevesinde kurumun oluşumu için gerekli asgari koşullar bulunmaktadır. Bunlar; bağımsız olması, yönetimin işlemleri, eylemleri ve davranışları ile ilgili geniş bir araştırma ve 
inceleme yapma hakkının olması ve mahkemeler gibi bağlayıcı kararlar alamamasıdır (Ünal, 2014, s.74). Bu koşulları ombudsmanlık kurumunun kurucu unsurları olarak değerlendirmek mümkündür. Ombudsmanın bağımsız olması; idare ve yürütmeye karşı korunması ve kendisinden beklenen faydayı sağlayabilmesi açısından önemlidir. Ombudsmana hiçbir makam veya merci emir ve talimat veremeyeceği gibi tavsiye ve telkinde de bulunamaz (Usta ve Akıncı, 2016, s.2739). Ombudsmanın bağımsızlığını sağlayan ombudsman kurumunu oluşturan anayasa ve kanunlar, seçilme biçimleri, dokunulmazlıkları, başka bir görev yapmaması, atanma usülü ve mali olanaklarıdır (Özden, 2010, s.38).

Ombudsmanın denetimin temel amacı hak ve özgürlüklerinin korunmasını sağlamaktır. Ancak ombudsmanlık denetiminde haksızlığının giderilmesi ile birlikte haksızlığın nedenleri ve nasıl giderileceğini bulmak için önerilerde bulunurken yönetimin iyileştirilmesi gibi bir katkıda bulunmaktadır (Avşar, 2012, s.55).

\section{Yerel Yönetim Ombudsmanlığı}

Ombudsmanlık her ülkede kendi kurallarına göre farklı şekillerde uygulanmaktadır. Ombudsmanlığı genel amaçlı, özel amaçlı, uluslararası ulus üstü, insan hakları ombudsmanı, yarı- ombudsmanlı, özek sektör ombudsmanlığı olarak sinıflandırmak mümkündür. Yerel yönetim ombudsmanlı̆̆ı genel amaçlı ombudsmanlık sınıflandırması içerisinde yer almaktadır (Ünal, 2014, s.88).

Yerel yönetim ombudsmanı merkezi yönetim ombudsmanlarının bütün özelliklerini taşıyan, yerel düzeyde, yerel yönetimlerin kötü işleyişinden kaynaklanan sorun çözmek, vatandaşların yerel yönetimlerdeki haklarını korumak ve yerel yönetimlerin daha iyi işlemesi amaciyla, yönetimin düzeltilmesine yönelik önerilerde bulunmak için oluşturulan ve müdahale alanları ölçüsünde otorite ve etkileri sınırlandırılan genel amaçlı ombudsmanlardır (Ünal, 2014, s.91). Yerel ombudsmanların denetim yetkileri hizmet sundukları belirli bir bölge veya şehirle sınırlıdır. Yerel yönetim ombudsmanı, mahalli ve müşterek sorunlarla ilgilenerek yerel yönetimlerin kötü yönetimine karşı halkı koruma görevi üstlenen ve şikayetlerle ilgilenen kurumlardır (Gökçe, 2013, s.9). 
Yerel yönetim ombudsmanlarının görev ve yetkileri anayasa ya da yasalarla belirlenmektedir (Sander, 2013, s.16). Yerel yönetim ombudsmanları parlamento ombudsmanları gibi atama ya da parlamento tarafından seçilerek gelmektedir. Yerel yönetim ombudsmanı olacak kişiler için yasalarda belli koşullar öngörülmüştür. Yerel yönetim ombudsmanın aldığı kararlar bağlayıcı değil tavsiye niteliğindedir. Hukuken ombudsmanın aldığı kararların yaptırım gücü yoktur. Ancak ombudsman kendisine iletilen yönetimle ilgili şikayetlerle ilgili inceleme yapmakta ve inceleme sonuçlarını raporlarla kamuoyu ile paylaşmaktadır (Sezen, 2001, s.76). Bu uygulama ombudsmana yönetim üzerinde bir etki yaratabilme olanağı sağlamaktadır. Yerel yönetim ombudsmanlığı insan haklarının korunmasına, yerel yönetimlerin hizmetlerinin geliştirilmesine katkıda bulunmakta ve yerel yönetimlere çözümler önermektedir. Sadece adil kararların değil, yönetim ve kararların kalitesinin güçlendirilmesine çalışmaktadır (Sander, 2013, s.13). Yerel yönetim ombudsmanlarının yerel yönetimlerin kötü yönetimden kaynaklanan eylem ve işlemlerinin düzeltilmesi, yerel düzeyde iyi yönetim uygulamalarının artırılması ve yönetimin iyileştirilmesi gibi faydaları söz konusudur (Ünal, 2014, s.102).

Yerel yönetim ombudsmanın denetiminin etkin olabilmesi için; bağımsızlığının ve tarafsızlığının güvence altına alınması, inceleme öncesinde her türlü bilgi ve belgeye ulaşabilmesi, ombudsmanlık konusunda kamuoyunda yeterli tanıtım ve bilgilendirmenin yapılması, kamu yönetimi ve işleyiş̧i hakkında bilgi sahibi olması, yerleşik siyasal ve yönetsel kültür ve toplumsal özellikler belirleyici faktörlerdir (Sezen, 2001, s.81-82). Yerel yönetim ombudsmanın görevini etkin bir şekilde yapabilmesi için yeterli mali olanaklara ve personele ihtiyacı vardır. Yerel yönetim ombudsmanlarına yardımcı olacak personel tahsis edilmekte ya da ombudsmanlar kendileri atamaktadır (Ünal, 2014, s.93).

Yerel yönetim ombudsmanlı̆̆1 ilk olarak 1974 yılından İngiltere'de oluşturulmuştur. 1981 yılında Kanada'da Prens Edwards Adası hariç bütün eyaletlerde yerel yönetim ombudsmanı kurulmuştur (Özden, 2010:101). İtalya'da bölge yönetimleri, Almanya, Avusturya ve Belçika'da özerk eyalet ve kantonlarda yerel ombudsmanlık kurumu oluşturulmuştur. İsviçre'de Basel Şehir Ombudsmanı ve Kanton Ombudsmanı bulunmaktadır (Kutlu, Örselli ve Kahraman, 2018, s.21) 


\section{İngiltere Yerel Yönetim Ombudsmanlığı}

Yerel yönetimler ombudsmanlığının Dünya'daki ilk örneği İngiltere Yerel Yönetimler Ombudsmanlığı'dır. Çalışmanın bu bölümünde ilk olması açısından öneme sahip olan İngiltere yerel yönetim ombudsmanlığının kuruluşu, işleyişi, faaliyetleri açılanacaktır. Ayrıca İngiltere Yerel Yönetim Ombudsmanlığı'nın faaliyet raporları ve müsşteri memnuniyeti anketlerindeki veriler çerçevesinde etkinliği değerlendirilecektir.

\section{İngiltere Yerel Yönetim Ombudsmanlı̆̆ının Kuruluş Süreci}

İngiltere'de ilk kurulan ombudsmanlık Parlamento Komiseridir. 1961 yılında hazırlanan Whyatt Komitesi Raporu ile kurulması öngörülmüştür. Ancak ombudsmanlık kurumu Parlamento Komiseri Kanunu ile 1967 yılında kurulmuştur (Arslan, 1986, s.158). Parlamento ombudsmanı siyasi ve yönetsel sürece yardımcı olarak atanmıştır ve parlamento adına çalışmaktadır. Parlamento ombudsmanı merkezi hükümet ve vatandaşlar arasındaki sorunlarla ilgilenmekle görevlidir. Parlamento ombudsmanı Avam ve Lordlar Kamarası'nın değerlendirmesi, hükümetin önerisi ile kraliçe tarafından atanmaktadır. Parlamento ombudsmanı görevi belli bir süreyle sınırlandırılmamış olup, 65 yaşına kadar görev yapabilmektedir. Parlamento Ombudsmanı kendi isteği ile ya da Parlamentónun uyarısı ve Kraliçe'nin onayı ile görevden alınabilmektedir (Parlak ve Doğan, 2019, ss.200-204).

Parlamento Ombudsmanı Hazine Bakanlığı tarafından, sayıları ve hizmet şartları onaylanması koşulu ile kurumu için yeterli personel istihdam edebilmektedir (Özden, 2010, s.87). Sağlık Hizmetleri Ombudsmanı 1973 yılında Ulusal Sağlık Hizmetlerinin Yeniden Yapılandırılması Yasası ile kurulmuştu. Kuzey İrlanda dışındaki Birleşik Krallığın diğer kurucu unsurları için ayrı seçiliyordu. İngiltere'de Sağlık Hizmetleri Ombudsmanlığı ile Parlamento Komiserliği Parlamento ve Sağlık Hizmetleri Ombudsmanı tek bir ombudsmanlık olarak birleştirilmiştir. Galler, İskoçya ve Kuzey İrlanda'da bu birleşme olmamıştır (Maer ve Priddy, 2018, s.14).

Ombudsmana başvuru eğer kamu yönetimi ve kamu kuruluşları ile ilgili ise şikayetin bir parlamento üyesi aracılığ 1 ile yapılması şarttır (Parlaimentary and Health Service Ombudsman, 2020). Konu kamu hastaneleri ile ilgili ise öncelikle hasta öneri ve iletişim hizmeti kurumuna şikayette bulunulmalıdır. 
Eğer o kurum tarafından sorun çözülemezse Parlamento ve Sağlık Hizmetleri Ombudsmanına başvurulmalıdır (NHS, 2020).

Yönetim için Parlamenter Komiseri ilk oluşturulduğu yılda yerel yönetimlerle ilgili atmış bir şikayet almış ancak yetki alanı dışında olduğu için şikayetleri geri çevirmiştir. 1969 yılında G. K Arran tarafından yerel yönetimlerin kötü yönetiminden şikayetlerle ilgili bir inceleme yapılmış olup, bu araştırmada yerel şikayetler için prosedür ihtiyacı ve uygulama için bir çatı önerilmiştir. Yerel yönetimler için yeterli sayıda ombudsmanın görevlendirilmesi gerektiğine dikkat çekilmiştir (Chinkin ve Bailey, 1976, s.268).

İngiltere' de 1971 yılında yayınlanan “Yerel Yönetimler Üzerine Beyaz Rapor "White Paper On the Local Government in England" yerel yönetimlere yönelik şikayetlerle ilgili prosedürün ne olacağına ilişkin olumlu bir belge olarak nitelendirilmektedir. 1974 Nisan' ında yürürlüğe giren "Yerel Yönetim Sözleşmesi" ile yerel ombudsmanlık oluşturulmuştur (Chinkin ve Bailey, 1976, ss. 267, 268). Yerel yönetimler ombudsmanlığının ortaya çıkmasında İngiltere'de Parlamento Komiserinin çalışmalarının başarılı olması etkili olmuştur (Ünal, 2014, s. 78).

\section{Ingiltere Yerel Yönetimler Ombudsmanlığının Organizasyon Yapısı ve İşleyişi}

1974 Yerel Yönetimler Sözleşmesinin (Local Government Act) üçüncü bölümü yerel yönetimler ombudsmanlığını düzenlemektedir. Yerel Yönetim ombudsmanlığında parlamento ombudsmanlığında olduğu gibi temel amaç kötü yönetimi ve haksızlıkla ilgili şikayetleri çözmektir. Ancak söz konusu sözleşmede kötü yönetim veya haksızlıkla ilgili bir tanımlama bulunmamaktadır (Chinkin ve Bailey, 1976, s.270). İngiliz hukuku çerçevesinde önyargılı, tarafll, dikkatsiz, keyfi ve gecikmeli davranışlar kötü yönetim olarak değerlendirilmektedir (Uyanık, 1994, s.206).

Yerel yönetim ombudsmanlığının bilinirliğini arttırmak için 1975 ilkbaharında İngiltere' de ülke genelinde kamuya açık yerlerde poster ve broşürler dağıtılmıştır. Aynı zamanda basında ve televizyonda daha fazla yer verilmiştir. Bu uygulama ile yerel yönetim ombudsmanlığına olan halk ilgisi artmıştır (Chinkin ve Bailey,1976, s.278). 
İngiltere'de yerel yönetim ombudsmanı Kraliçe tarafından atanmaktadır. Görevden alınması da yetkide paralellik çerçevesinde yine aynı şekilde olmaktadır. İngiltere' de yerel yönetim ombudsmanı olacak kişi için yasada öğrenim düzeyi belirtilmemiştir. Uygulamalar incelendiğinde genellikle yüksek öğrenim görmüş kişiler ombudsman olarak atanmaktadır (Ünal, 2014, ss.92-93). İngiltere'de yerel ombudsmanlık kurulduğu 1974 yılında her birinin görev alanı belli bir coğrafi bölge olan üç yerel yönetim ombudsmanı bulunmaktaydı. 2010 yılında yapılan düzenlemeyle görev alanları konu ile s1nurlı olan iki yerel yönetim ombudsmanı görevlendirilmiştir (Kavili Arap, 2015, s.69). Şu anda tek ombudsman bulunmaktadır. İngiltere Yerel Yönetimler Ombudsmanlığı 2017 yılında yapılan değişiklikle İngiltere Yerel Yönetimler ve Sosyal Hizmet Ombudsmanlığı (IYSHO) olarak birleştirilmiştir.

İYSHO daha işlevsel hale gelebilmesi için tarihsel süreçte değişiklikler yapılmıştır. IYYSHO'ya şikayet başvurusunda bulunma konusunda 1988 yılında yapılan Fresh Local Government Act ile önemli bir değişiklik gerçekleştirilmiştir. Şikayet başvurusu yapabilmek için yerel yönetim meclis üyesinin referansının gerekliliği kaldırarak doğrudan başvuru imkanı sağlanmıştır. Ayrıca 2007 yılında Parlamento ve Sağlık Ombudsmanı ile birlikte çalışma ve bilgi paylaşımı yapabileceklerine yönelik düzenleme yapılmıştır. 2007 yılında Yerel Yönetimler ve Halkın Katılımı Yasası (Local Government and Public Involvement Act) ile yerel ombudsmanlığın yetkileri arttırılmıştır. Yapılan değişiklikler aşağıdaki gibidir (Thomas, Martin ve Kirkham, 2013, ss.83-84):

- Kötü yönetim ile birlikte yerel yönetimlerin hizmet kusurlarını inceleme yetkisi verilmiştir.

- Kötü yönetimi olduğu açık şekilde belliyse konuyla ilgili şikayete gerek olmadan sınırlı inceleme yetkisi verilmiştir.

- Mal ve hizmet temin edilmesi konusunda ortaya çıkan şikayetleri inceleme yetkisi verilmiştir.

- Belediye meclisinin kararı şikayeti ortadan kaldırıyorsa konuyla ilgili ombudsmana sadece sözlü açıklama yapması yetkisi tanınmıştır.

- Şikayetleri sözlü de alabilme yetkisi verilmiştir.

2009 yılında yürürlüğe giren Sağlık Yasası (Health Act) ile kendi kaynakları ile sosyal bakım hizmeti alan yetişkinlerin sosyal bakım hizmeti veren kuruluşlarla ilgili şikayetleri almaya başlamıştır. 
İYSHO bütün yerel yönetimler ve yetişkinlere yönelik sosyal hizmet sağlayıcıları ile ilgili şikayetleri incelemektedir. Ayrıca ombudsmanlık kuruluşlara yönelik de inceleme de bulunabilmektedir. Okula kabul, yerel otoritelerin ortak kurulları, milli park yönetimleri, içsel drenaj kurulları, Belediye başkanlığ1 suç ve polis ofisi (inceleme ve suçu önlemek için değil), yangin ve kurtarma otoriteleri, Londra Yangin ve Acil Durum Planlama Otoritesi, Büyük Londra Yönetimi, Londra için Ulaşım, Londra Kalkınma Ajansı, kent kalkınma ortaklıkları, Belediye Başkanlı̆̆ı Geliştirme Şirketi, Evler ve Topluluklar Ajansı, sadece sele karşı savunma ve arazi drenajıyla sınırlı olmak üzere Çevre Ajansı ile ilgili şikayetleri de incelemektedir İYSHO planlama, bazı konut konuları, sosyal hizmet, eğitim ve okulla ilgili sorunlar, konut yardımı, belediye vergileri, ulaşım ve karayolları, çevre ve atıklar, komşularla olan anlaşmazlıklar, antisosyal davranışları incelemektedir. Şikayet edilen konular diğer ombudsmanların görev alanı içinde yer alıyorsa İYYSHO işbirliği içinde çalışmaktadır (LGOa, 2020).

İYSH, hizmetlerini İngiltere Yerel Yönetim Komisyonu resmi adı ile yürütmektedir. Bağımsız olup, mali açıdan devlet tarafından destek almaktadır. Yerel yönetim ombudsmanı, parlamento ombudsmanı ve üç danışma üyesi olmak üzere 5 kişiden oluşan yönetim komisyonu kurumun stratejik yönetimden sorumludurlar. Komisyon üç ayda bir toplanmaktadır. İnceleme için ombudsmana personel, konaklama yeri, bilgi ve iletişim teknolojileri gibi gereken desteği sağlamak görevi vardır. Mali tahminleri, yıllık raporları yıllık iş planı, dört yıllık stratejik planı, kaynakların ve bütçenin onaylanması da görevleri içindedir. Yerel Yönetim Yasası (1974) her üç yılda bir ombudsmanlıkla ilgili olan üçüncü bölümü ile ilgili değerlendirme yapılması, ombudsman hizmetinin yararlarını ve ücretlerini Ücret ve Atama Komitesinin önerilerini dikkate alarak kararlaştırmak görevleri arasındadır. Komisyon üyelerinin etik davranmasına yönelik olarak her üye etik kodlar sözleşmesinin imzalamak ve çıkarlar deklarasyonu doldurmak zorundadır. Ombudsmanın incelemeler sırasında kurum dışı yaptığı görüşmeleri komisyona bildirmekte ve yayınlanmaktadır (LGOb, 2020).

Herkes ücretsiz olarak şikayet başvurusunda bulunabilir. Kişi yasal temsilcisi ve iznini aldığı kişiler adına başvuru yapabilmektedir. Meclis üyesi ya da milletvekili yerel halk adına izinlerini alarak başvurabilmektedir. Şikayet bir hizmetle ilgili ise doğrudan hizmet aldığı ve kişisel olarak etkilenmesi şar- 
tyyla, sadece kendi yerel meclisiyle ilgili şikayette bulunulabilir. İngiltere yerel yönetim ombudsmanı 4 aşamada şikayeti incelemektedir. İlk olarak şikayet incelenmekte olup, şikayetin yetki alanı içerisinde yer alıp yer almadığına bakılmaktadır. Şikayet kabul edildiğinde şikayetçi ve şikayet edilen kurumdan gerekli bilgiler istenmektedir (LGOa, 2020). Ombudsmanlık şikayeti dikkate alarak kuruma doğru olan şeyi çözüm olarak önermektedir. Ayrıca eğer şikayet konusu olan sorun kurum tarafından çözüme kavuşturulduysa ve şikayet ele alındığında kişi üzerinde belirgin olumsuz bir etkisi olmadığına karar verilirse herhangi bir öneride bulunulmamaktadır. Şikayet dikkate alınmaz ya da incelenmez (Local Government Act, 1974).

Yerel ombudsmanlık kötü yönetim ve kusurlu hizmetten dolayı oluşan haksızlığı tazmin etmeye yönelik önerilerde bulunmaktadır. Yapmış olduğu incelemelerle iyi yönetimi ilerletmek ve yerel hizmet sunumunu geliştirmeye yönelik temel oluşturmak ombudsmanın sorumluluğudur (LGO Framework Document, 2017, s.5). Kötü yönetimin ne olduğu kanunlarda açıkça belirtilmemiştir. Yerel Yönetim Ombudsmanının web sayfasındaki tavsiye kararları çerçevesinde ortak noktalar belirlenmiştir. Bunları aşağıdaki gibi açıklayabiliriz (Sandford, 2017, s.5):

-Hizmette gecikme,

-Yanlış işlem yapılması,

-Yasal sürecin takibinde yapılan yanlışlıklar,

-İnceleme hatası,

-Yetersiz iletişim

-Yanıltıcı bilgi vermek

-Kurumun görevini yerine getirmemesi

Ombudsmanlık kurumu farklı kararlar alabilmektedir. Kurumun kişilerden özür dilemesini, verilmesini gereken standartta hizmetin sunulması, önceden verilmesi gereken kararın verilmesi, tekrar edebilecek benzer sorunlara yönelik sürecin geliştirilmesi, bir ödeme yapılması gibi kararlar verilmektedir. Ancak ombudsmanlığın aldığı kararlar tavsiye niteliğindedir. Ombudsmanlık kararları alındıktan üç ay sonra kişilerin gerçek ismi kullanılmadan yayınlamaktadır. Ayrıca kararların rapor örneği medyaya gönderilmektedir (LGOa, 2020). Bu uygulama yerel yönetimler ombudsmanlığının etkili olması açısından olumlu katkı sağlayabilir._Yerel yönetimler ombudsmanlığı yapmış olduğu faaliyetlerle ilgili yıllık rapor hazırlanmakta ve bu raporlar web 
sayfası üzerinden yayınlanmaktadır. Raporlarda yerel yönetimlerle ilgili şikayetler konularına göre sınıflandırılmakta ve veriler paylaşılmaktadır (LGO Framework Document, 2017, s.6). Hizmetlerde açıklığın ve kurumun hesap verilebilirliğinin sağlanması konusunda yapılan bu uygulamalar olumlu olarak değerlendirilebilir.

\section{Ingiltere Yerel Yönetim Ombudsmanlı̆̆ıın Etkinliği}

İngiltere Yerel Yönetim Ombudsmanlı̆ı̆ın etkinliği 2013-2019 arasındaki yıllık raporları ve 2014-2018 yılları arasında müşteri memnuniyeti anketlerindeki verileri çerçevesinde incelenecektir. Bu çalışmada yerel yönetim ombudsmanlığının etkinliği; şikayetlerin inceleme hızı, ombudsman kurumunun verdiği hizmet ve kararlardan şikayetçilerin memnuniyet derecesi ile mali açıdan başlıkları çerçevesinde analiz edilecektir.

\section{Şikayetlerin İnceleme Hizı}

Yerel yönetim ombudsmanlığı kendisine iletilen şikayetleri üç aşamada incelemektedir (LGO, 2018-2019 Annual Report and Acoounts: s.4):

- Birinci aşama ilk kontrol aşamasıdır. Bu aşamada öncelikle, yerel yönetimler ya da hizmet verenler bu şikayeti çözebilir mi? Şikayetçi haklı mı değil mi? Bu sorulara cevap aranmaktadır.

- İkinci aşama ilk değerlendirme aşamasıdır. Bu aşamada şikayet konusu hukuken görev alanı içerisinde mi? Bu soruya cevap aranmaktadır.

- Üçüncü aşama detaylı inceleme aşamasıdır. Hukuk ve politikalara göre ne olduğu ve ne olması gerektiği incelenmektedir. Yapılan inceleme sonucunda şikayet haklı bulunursa önerilerde bulunulmaktadır.

Yerel yönetimler ombudsmanlığının şikayeti incelemesi için yasal bir süre sinırlandırması bulunmamaktadır (Kavili Arap, 2015, s.71). Ancak yerel yönetimler ombudsmanlığını kalite hedefleri arasında olabildiğince en kısa sürede şikayetleri incelemek yer almaktadır. 2013 ve 2019 dönemleri arasındaki yıllık raporlarda en kısa 13 hafta ve en uzun 52 hafta arasında değişen sürelerde şikayetlerin incelendiği görülmektedir. 
Tablo 1. İngiltere Yerel Yönetim Ombudsmanlı̆̆ının 2013-2019 Yıllarn Arasında Karar Verme Sürelerinin Dağılımı

\begin{tabular}{llll}
\hline Yll & 13 Hafta & 26 Hafta & 52 Hafta \\
\hline $2013-2014$ & $\% 68$ & $\% 90$ & $\% 99$ \\
\hline $2014-2015$ & $\% 83$ & $\% 94$ & $\% 99$ \\
\hline $2015-2016$ & $\% 80$ & $\% 91$ & $\% 99$ \\
\hline $2016-2017$ & $\% 79$ & $\% 92$ & $\% 99$ \\
\hline $2017-2018$ & $\% 79$ & $\% 91$ & $\% 99$ \\
\hline $2018-2019$ & $\% 78$ & $\% 90$ & $\% 99$ \\
\hline
\end{tabular}

Kaynak: İngiltere Yerel Yönetim Ombudsmanlığı yıllık raporlarından yararlanılarak yazar tarafından hazırlanmıştır.

Tablo 1'deki verileri değerlendirdiğimizde 13 hafta içerisinde karar verilen şikayetlerin oranı 2013 yılından 2019 yılına kadar olan süreçte önemli oranda bir artı̧ göstermiştir. 2013- 2019 döneminde 52 hafta şikayetlerin tamamına yakını hakkında karar verildiğini söylemek mümkündür.

Tablo 2. Ingiltere Yerel Yönetim Ombudsmanına Gelen Şikayet Sayısı

\begin{tabular}{llll}
\hline Yll & Gelen Şikayet Sayısı & $\begin{array}{l}\text { Değerlendirilen } \\
\text { Şikayet Sayıs }\end{array}$ & $\begin{array}{l}\text { Incelemeye Alınan } \\
\text { Şikayet Sayısı }\end{array}$ \\
\hline $2013-2014$ & 20306 & 11725 & 5680 \\
\hline $2014-2015$ & 20286 & 11094 & 4780 \\
\hline $2015-2016$ & 20102 & 11094 & 4792 \\
\hline $2016-2017$ & 19077 & 11526 & 4771 \\
\hline $2017-2018$ & 17452 & 8135 & 4808 \\
\hline $2018-2019$ & 18482 & 8709 & 4458 \\
\hline
\end{tabular}

Kaynak: 2013 -2019 yılları arasındaki İngiltere Yerel Yönetim Ombudsmanlığı yıllık raporlardan yararlanılarak yazar tarafından hazırlanmıştır. 


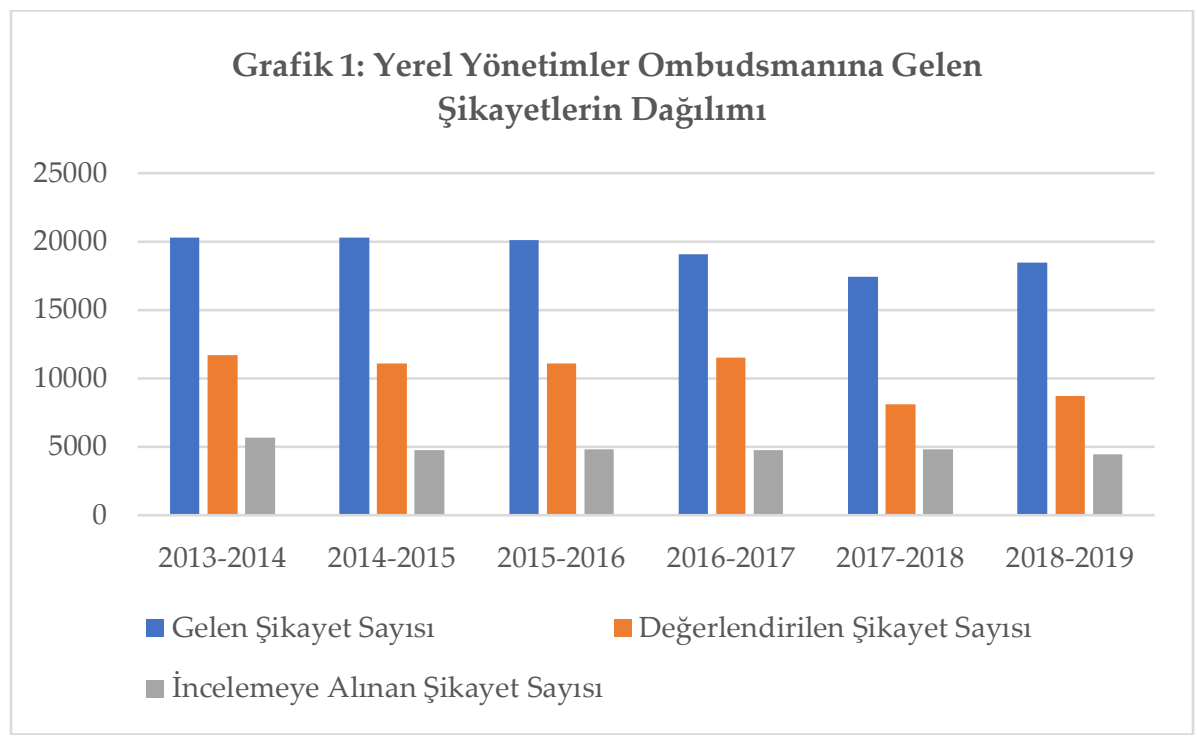

2016 yılından sonra toplam başvuru sayısı ve değerlendirmeye alınan başvuru sayısının önceki yıllara göre azaldığı görülmektedir. Yıllar içinde değerlendirmeye alınan şikayet sayısında önemli bir farklılık görülmemektedir. Ayrıca daha önceki bölümde açıklanan ilk aşamada gelen şikayetlerin yarısından fazlası değerlendirme aşamasına geçmekte, üçüncü aşamada ise yine gelen şikayetlerin incelemeye alınanlara oranı yaklaşık olarak dörtte birini geçmemektedir. Bu veriler daha önceki yapılan çalışmalardaki sonuçları doğrular niteliktedir. Vatandaşların başvuru koşullarını bilmemesi, yetersiz bilgi sahibi olması ve doğru yönlendirilmemesi gelen şikayet başvurusunun say1sının yüksek olması gibi nedenlerin hala etkili olduğunu göstermektedir (Kavili Arap, 2015, s.71).

Yerel ombudsmanlığın etkinliğini yerel yönetimlerle olan ilişkileri de etkilemektedir. Ombudsmanlıkça sunulan önerilerin yerel yönetimlerce ne kadar yerine getirildiği önemlidir. 2018'de yerel yönetimlerin küçük bir kısmı ile önerilerin dikkate alınıp alınmadığı ve nasıl uygulandığına yönelik pilot proje gerçekleştirilmiştir. 2019-2020 döneminden itibaren interaktif harita ile yerel yönetimlerle ilgili güncel veriler raporlanarak paylaşılması öngörülmektedir. Bu yeni sistemle uzlaşılan haksızlıklar konusunda yerel yönetimlerin gerekli veriye sahip olması ve müşteri memnuniyetini arttırması gibi faydalar beklenmektedir (LGO Final Complaint Report, 2017, s.14). 
Yerel yönetimler ombudsmanlığı düzenleyici işlevi çerçevesinde yerel seçilmiş meclislere demokratik hesapverilebilirlikle ilgili önerilerde bulunmaktadır. Bu önerilerin uygulama zorunluluğu olmamasına rağmen uygulanmaktadır. Verilen kararı yerine getirmeyen yerel meclis veya hizmet veren kurumlar yayınlanan raporlarda belirtilmektedir. Bu uygulama neden ilgili yerel yönetimin ya da kurumun neden öneriyi uygulamadığını açıklaması durumunu ortaya çıkarmaktadır. Yayınlanan raporlarda tekrar edilen hatalar, belirgin kusurlar, haksızlıklar, yüksek oranda şikayet edilen konular ve uyulmayan öneriler bulunmaktadır (LGO 2017-2018 Annual Report and Accounts, 20). Bu uygulama yerel yönetimlerin yerel halka karşı hesapverme zorunluluğunu ortaya çıkarmaktadır. Ayrıca yapılan hataların belirlenmesi iyi yönetimin geliştirilmesine katkı sağlayacaktır.

2017-2018 yıllık raporda yerel yönetim ombudsmanlığının yerel hizmetleri geliştirilmesi noktasında yerel meclislerin memnuniyeti \%100'dür. Ancak yerel meclislerin ancak $\% 9^{\prime} u$ verilen kararın adil ve uygun olduğunu düşünmektedir (LGO 2017-2018 Annual Report, s.25). 2018-2019 Yıllık raporuna göre yerel meclis ve hizmet veren kurumların \%99,4'ü önerileri uygulamıştır (LGO 2018-2019 Annual Report and Accounts, s.7)

\section{Müssteri Memnuniyeti Anketleri}

Müşteri memnuniyeti anketleri müşterilerin tecrübelerini ve hizmetlerden memnuniyetini, hizmetlerin geliştirilmesi gereken noktaları, zaman içerisindeki performansını belirlemek için Nisan 2014' den itibaren kurum tarafından yapılmaktadır. Müş̧eri memnuniyeti anketleri şikayeti ile ilgili karar verilen müşterilere kararın verilmesinden 6 hafta sonra yapılmaktadır. Memnuniyet anketleri şikayeti ile ilgili karar verilen şikayetçilerle telefonla gerçekleştirilmektedir (LGOc, 2020).

Tablo 3. Ingiltere Yerel Yönetim Ombudsmanlı̆̆ının Vermiş Olduğu Hizmetten Memnuniyet Derecesi

\begin{tabular}{llll}
\hline Yil & Memnun (\%) & Kararsiz (\%) & Memnun Değil (\%) \\
\hline $2014-2015$ & 24 & Veri yok & 68 \\
\hline $2015-2016$ & 27 & 11 & 62 \\
\hline $2016-2017$ & 27 & 11 & 76 \\
\hline $2017-2018$ & 26 & 11 & 63 \\
\hline
\end{tabular}

Kaynak: İngiltere Yerel Yönetimler Ombudsmanlığı müşteri memnuniyeti anketlerinden yararlanılarak yazar tarafından hazırlanmıştır. 
Yerel yönetim ombudsmanlığının şikayetin ele alınış sürecinde vermiş olduğu hizmetten 2014- 2018 yılları arasında memnuniyetsizlik oranı oldukça yüksektir. Ayrıca hizmetlerden memnun olanların oranında yıllar itibariyle küçük bir artşs söz konusudur.

Tablo 4. Şikayet Sonucunda Yerel Yönetim Ombudsmanlı̆̆ının Vermiş Olduğu Karardan Memnuniyet Derecesi

\begin{tabular}{llll}
\hline Y1l & Memnun (\%) & Kararsiz (\%) & Memnun Değil (\%) \\
\hline $2015-2016$ & 17 & 6 & 77 \\
\hline $2016-2017$ & 19 & 6 & 76 \\
\hline $2017-2018$ & 19 & 6 & 76 \\
\hline
\end{tabular}

Kaynak: İngiltere Yerel Yönetimler Ombudsmanlığı Müşteri Memnuniyeti anketlerinden yararlanılarak yazar tarafından hazırlanmıştır.

Yerel yönetim ombudsmanının şikayetlerle ilgili vermiş olduğu kararlardan 2015-2018 yılları arasında katılımcıların yüzde 75'i memnun değildir. Memnun olanların oranında sadece yüzde ikilik bir artış söz konusudur.

Tablo 5. Şikayet Sonucu Oluşturulan Raporun Sonucu Yeterince Açıklamasına Yönelik Görüşlerin Dağılımı

\begin{tabular}{llll}
\hline Tarih & Açı (\%) & $\begin{array}{l}\text { Takip Edilmesi } \\
\text { Kolay (\%) }\end{array}$ & $\begin{array}{l}\text { Kullanılan Dilin Basit } \\
\text { ve Anlaşılır Olması } \\
\text { (\%) }\end{array}$ \\
\hline $2015-2016$ & 64 & 65 & 75 \\
\hline $2016-2017$ & 63 & 64 & 73 \\
\hline $2017-2018$ & 72 & 63 & 60 \\
\hline
\end{tabular}

Kaynak: İngiltere Yerel Yönetimler Ombudsmanlığı Müşteri Memnuniyeti anketlerinden yararlanılarak yazar tarafından hazırlanmıştır.

Raporun açık olmasında yıllar itibariyle bir artış söz konusu iken, kullanılan dilin basit ve anlaşılır olmasında önemli oranda bir azalış söz konusudur. $\mathrm{Bu}$ veriler çerçevesinde verilen kararların anlaşılması zorlaşmaktadır. Bu durum şikayetçinin karara yönelik değerlendirmelerini olumsuz etkileyerek, memnuniyetsizliğini arttıracaktır.

Yapılan dört müşteri memnuniyeti anketinde memnuniyetsizliklerinin neden kaynaklandığına dair sorular yöneltilmiştir. Yapılan anketlerde personelin iletişim tarzı, nazik olması konusundan yüzde 70'lerin üzerinde bütün raporlarda memnuniyet oranı söz konusudur. Memnun olunmama nedenleri olarak en yüksek orana sahip olunan nedenler; karar verilirken kendi 
görüşlerinin dikkate alınmaması, şikayetin karar sürecinin uzun olması, kararın adil olmamasıdır. Bunlar müşterilerin verilen karardan tatmin olmamasını sağlamaktadır. Ayrıca verilen hizmet ve karardan memnun olunmamasını da açıklamaktadır. 2016 yılında şikayetçilerin süreç hakkında bilgilendirmesini sağlamak ve memnuniyetlerini arttırmaya yönelik şikayetlerin durumunu her an takip edebilecekleri ek bir iletişim kanalı oluşturulmuştur (LGO 2015-2016 Customer Satisfaction Annual Report, s.10).

2015-2016 memnuniyet anketinde ayrıca memnuniyetsizliğin giderilebilmesi için müşterilere neler yapılması konusunda öneriler sorulmuştur. 1045 öneri gelmiş olup, maddi tazminat (\%27), şikayet edilen kurumun şikayetçiden özür dilemesi (\%26), uygulama, politikalar ve sürecin yeniden gözden geçirilmesi (\%20) ve daha uygulanabilir kararlar (\%15) olarak belirtilmiştir (LGO 2015-2016 Customer Satisfaction Annual Report, s.13).

\section{Mali Açıdan Etkinliği}

İngiltere Yerel Yönetimler Ombudsmanlığı bütçesi İskan, Topluluklar ve Yerel Yönetimler Bakanlığı (Ministry of Housing, Communities and Local Government) bütçesinden aktarılmaktadır. 2010- 2011 yılları arasında kurumun bütçesi 16.8 milyon sterlin iken, 2014-2015 döneminde bütçe 11.2. milyon sterline düşürülerek önemli bir azalış olmuştur. Personel sayısı 228' den 158'e düşürülmüştür (LGO 2014-2015 Annual Report and Accounts, s.1). 2019 yılı verilerine göre kurumun personel sayısı 172' dir. Beş yıllık süre içerisinde başvuru sayısı artmasına rağmen, personel sayısında önemli bir artış olmamıştır. Şikayetin inceleme ve değerlendirme sürecinin uzun olmasında personel sayısının yetersizliği önemli bir neden olarak değerlendirilebilir.

Ombudsmanlığa güvenilebilmesi için hesapverebilir olması önem taşımaktadır. Bütçe ve iş planları ombudsman dahil beş kişiden oluşan ombudsman yönetimince hazırlanmaktadır. Denetim ve Risk Güvence Komitesi (Audit and Risk Assurance Committee) ile Ücretlendirme Komitesi (Remuneration Committee) tarafından hazırlanan bütçe ve iş planları incelenmektedir. Görüşme tutanakları, Denetim ve Risk Güvence Komitesi tutanakları yayınlanmaktadır. Hizmetlerle ilgili şikayetler bağımsız bir denetleyici tarafından incelenmektedir (LGO 2017-2018 Annual Report and Acoounts, s.28). 
Tablo 6. Ingiltere Yerel Yönetim Ombudsmanlığının 2014-2019 Yıllarn Arasındaki Bütçesi

\begin{tabular}{ll}
\hline Tarih Aralı̆̆ & Bütçe Miktarı \& \\
\hline $2014-2015$ & 11.2 milyon \\
\hline $2015-2016$ & 11.264 milyon \\
\hline $2016-2017$ & 11.993 milyon \\
\hline $2017-2018$ & 13.898 milyon \\
\hline $2018-2019$ & 13.276 milyon \\
\hline
\end{tabular}

Kaynak: İngiltere Yerel Yönetim Ombudsmanlığının 2014-2019 yılları arasındaki yıllık raporlarından yararlanılarak hazırlanmıştır.

2014- 2019 yılları arasında bütçedeki değişim önemli oranda bir artış söz konusu değildir. 5 yıllık süre içerisinde bütçede $\% 15$ oranında bir artış olmuştur. İngiltere yerel yönetim ombudsmanlığının şikayetin değerlendirme süresinin daha kısa olması ve şikayetçilerin memnuniyetin artabilmesi için bütçe ve personel açısından desteklenmesi önemlidir.

\section{Sonuç}

Ombudsman devlet ile vatandaş arasındaki ilişkilerde ortaya çıkan sorunlarla ilgili şikayetleri inceleyen bağımsız ve tarafsız bir denetim aracıdır. Tarihsel süreçte temelleri ilk olarak İsveç' te atılmış olup, daha sonra diğer ülkelerde uygulanmaya başlamıştır. İngiltere'de 1961 yılında Parlamento Komiseri adıyla ombudsmanlık kurulmuştur. Parlamento Komiserinin başarılı olması ve yerel yönetimlerle ilgili şikayetlerin artması yerel yönetim ombudsmanlığa ihtiyacı ortaya çıarmıştır. 1974 yılında dünyadaki ilk yerel yönetim ombudsmanlığı İngiltere' de oluşturulmuştur.

İngiltere yerel yönetim ombudsmanlı̆̆ kurulduğu günden bugüne kadar geçen süreçte ihtiyaç ve beklentilere göre yapı işleyiş değişikliğine gitmiştir. 2012 yılında özellikle bir dönüşüm süreci başlatmıştır. Bu çalışmada İngiltere yerel yönetim ombudsmanlığının 2013- 2019 yılları arasındaki etkinliği incelenmiştir. Yerel yönetimler ombudsmanın etkinliği incelenen şikayet sayısı, şikayetlerin incelenme hızı, hizmetlerde ve kararlardan memnuniyet ve mali açlardan analiz edilmiştir.

Gelen şikayet sayısı yıllar itibariyle artmasına rağmen, incelenen şikayet sayısı gelen şikayet sayısının dörtte biri kadardır. Bu sonuç 2013 yılından önceki dönemlerdeki incelenen şikayet sayısı oranı ile aynıdır. Bu açıdan bir olumlu gelişme olmamıştır. Şikayetlerin inceleme hızı da 13-52 hafta arasında 
değişmektedir. Şikayetlerin tamamının incelenmesi bir yıldan uzun sürmektedir Bu sonuç vatandaşların yerel yönetim ombudsmanlığına başvurmasını olumsuz etkilemektedir.

Yapılan çalışma ile hizmetlerden ve kararlardan memnuniyet düzeyinde yıllar itibariyle belirgin bir artış olmadığı sonucuna ulaşılmıştır. İnceleme sürecinin uzun olması, kararda şikayetçi olanların kendi görüşünün dikkate alınmaması ve verilen kararın adil olmaması memnuniyetsizliğin temel nedenleri olarak öne sürülmektedir. Hizmetten ve kararlardan memnuniyetin artabilmesi için öncelikle şikayetin inceleme süresinin olabildiğince kısaltılması gereklidir. Ayrıca karar verme konusunda şikayetçi ile daha fazla görüşme gerçekleştirilmelidir.

İngiltere Yerel Yönetim Ombudsmanlığı tavsiye niteliğinde kararlar verdiği için verilen kararların uygulanma oranı belirlenmelidir. Bu açıdan yerel yönetimlerle ilişkiler ve iletişimin arttırılması gereklidir. Bu ihtiyaca yönelik olarak yerel yönetimlere yönelik bir veri tabanı ombudsmanlık bünyesinde oluşturulmuştur. Ayrıca yerel yönetimlerin kararları ne kadar uyguladığına yönelik bilgiler toplanmaktadır. Bu olumlu bir gelişme olarak değerlendirilebilir.

Bu çalışmada İngiltere yerel yönetim ombudsmanlığının mali açıdan analizi yapılmıştır. Analiz sonucunda daha önceki dönemlere göre bütçede ve personel sayısında bir azalma olmuştur. Bütçede ve personel sayısında son yıllarda da çok belirgin bir artış söz konusu değildir. Bütçe ve personelin yeterli olması yerel yönetim ombudsmanlığının etkinliği için şarttır. Yerel yönetim ombudsmanlığının incelediği şikayet sayısı, şikayetin incelenme süresi, karar ve hizmetlerden memnuniyetteki problemlerin giderilebilmesi için bütçede ve personel sayısında artışa gidilmelidir.

Sonuç olarak İngiltere Yerel Yönetim Ombudsmanlı̆̆ı kurulduğu yıldan günümüze kadar geçen süreçte yerel yönetimlerle ilgili şikayetlerin incelenmesi açısından geliştirilmesi gereken noktalar olmasına rağmen önemli bir örnek olarak nitelendirilebilir. Türkiye'de yerel yönetimlerle ilgili başvurular Kamu Denetçiliği Kurumu tarafından alınmaktadır. Kamu Denetçiliği Kurumu'nun faaliyet raporları incelendiğinde yıllar itibariyle yerel yönetimlerle ilgili başvuru sayısında yüksek bir artış söz konusudur. Türkiye'de de yerel yönetimlerle ilgili görev yapacak yerel yönetimler ombudsmanlığı kurulması uygun olacaktır. 


\section{EXTENDED ABSTRACT}

\section{An Evaluation About Effectiveness of England Local Government Ombudsman

\author{
Melike Erdoğan \\ Çanakkale Onsekiz Mart University
}

Public administration is supervised in different ways to protect the rights of the governed. There are administrative audits, judicial control, and extrajudicial control in auditing the public administration. The foundation of the ombudsman institution was laid in Sweden in the $18^{\text {th }}$ century as a method of extrajudicial control. The Ombudsman is an institution examining and mediating the complaints arising from the relations between the administration and the citizen. Successful practices of the Swedish Ombudsman have led to the establishment of the ombudsman institution in other countries, especially in the Scandinavian countries. States have started to establish ombudsman institutions Whose authority are different fields according to the conditions and needs of their countries. One of them is the local government ombudsman examining the complaints arising from the relations between local governments and local people whose authority is limited in the field of service. The requirement to establish local government institutions has emerged due to the supervision of local governments and the increase in their duties. The local government ombudsman analyzes the complaints arising in the relations between local governments and the citizen. The local government ombudsman first was established in England in 1974 and then it was started to put into service in different countries. The structure and functions of the England Local Government Ombudsman, which is the first example of a local government ombudsman, are examined in this study accordingly. The aim of this study is to demonstrate the effectiveness of the England Local Government Ombudsman in terms of citizen satisfaction for the provision of the services and financial. The study has been carried out by examining the documentation of England Local Government Ombudsman's annual reports and customer satisfaction surveys between 2013-2019. The England Local Government Ombudsman has changed its structure according to needs and expectations in the process that has elapsed since its establishment. It started 
a particular transformation process in 2012. In this study, the effectiveness of the England Local Government Ombudsman between the period 2013-2019 has been examined. Although the number of complaints has increased over the years, the number of complaints examined is one-fourth of the number of complaints received. This result is the same as the ratio of the number of complaints examined in the periods prior to the year 2013. There has been no improvement in this regard. The review pace of the complaints also varies between 13-52 weeks. It takes more than a year to review the entire complaints. As a result of the study, it was concluded that there was no significant increase in the level of satisfaction with the services and decisions over the years. The main reasons for dissatisfaction are cited as the lengthy examination process, the negligence of the opinion of the complainants in the decision, and the unfairness of the decision. In order to increase satisfaction with the service and the decisions, first of all, the examination period of the complaint is required to be shortened as much as possible. In addition, more discussions should be held with the complainant about decision making. Since the England Local Government Ombudsman makes advisory decisions, the implementation rate of the decisions should be determined. In this respect, it is necessary to increase relations and communication with local governments. For this requirement, a database for local governments has been created within the ombudsman. Besides, information is collected on how many local governments implement the decisions. This can be considered as a positive development. In this study, the financial analysis of the England Local Government Ombudsman was made. As a result of the analysis, there has been a decrease in the budget and the number of personnel compared to the previous periods. There has not been a significant increase in the budget and the number of personnel in recent years. Adequate budget and personnel are essential for the efficient functioning of the local government ombudsman. The number of complaints examined by the local government ombudsman, the period of examination of the complaint, the budget and the number of personnel are required to be increased in order to eliminate the problems in the overall satisfaction with the decisions and services.

Consequently, the England Local Government Ombudsman can be regarded as an important example for 46 years, although there are points that need to be improved in terms of examining complaints about local governments. 
The Ombudsman Institution gets complaints about local governments in Turkey. When the annual reports of the Ombudsman Institution are examined between 2013-2020, there is a high increase in the number of complaints related to local governments over the years. A local government ombudsman that examines complaints about local governments should be established in Turkey.

\section{Kaynakça / References}

Arslan, S. (1987). İngiltere'de ombudsman müessesesi. Amme İdaresi Dergisi, 19(1), 157172.

Avşar, Z. (2012). Ombudsman (kamu hakemi) Türkiye için bir model önerisi. Hak-Işs Federasyonu, Ankara.

Baylan, Ö. (1978). Vatandaşın devlet yönetimi hakknndaki şikayeti ve Türkiye için İsveç ombudsman modeli. Içişleri Bakanlığı Teftiş Kurulu Başkanlığı Yayınları, Ankara.

Chinkin C. M. and Bailey, R.J. (1976). The local ombudsman. Public Administration, 54, 267-282.

Erhürman, T. (1998). Ombudsman. Amme İdaresi Dergisi, 31(3), 87-103.

Erylmaz, B. (2014). Kamu yönetimi düşünceler yaplar fonksiyonlar politikalar. Umuttepe Yayınları, İstanbul.

Fendoğlu, H. T. (2017). Cumhurbaşkanlığı sisteminde ombudsman denetimi: idarenin kamu denetçiliği kurumu tarafindan denetlenmesi. Ombudsman Akademik, 5, 14-36.

Gökçe, A. F. (2013). Kamu denetçiliği kapsammda mahalli idarelerde ombudsman denetimi. KAYSEM-8 Kuramdan Uygulamaya Yerel Yönetimler ve Kentsel Politikalar Bildiri Kitabl, 11-12 Mayss 2013, Hatay, 1-9.

International Ombudsman Institue (t.y). The IOI. 07.04.2020 tarihinde https://www.theioi.org/the-i-o-i adresinden erişilmiştir.

Kavili Arap, S. (2015). 40. yllinda İngiltere'de yerel yönetim ombudsmanı. Ege Akademik Bakış, 15 (1), 65-80.

Kutlu, Ö. Örselli, E. ve Kahraman, S. (2018). Türkiye'de yerel ombudsmanlığın uygulanabilirliği: italya yerel ombudsmanlığı üzerinden bir analiz._Ombudsman Akademik, 8, 15-38.

Legislation.gov.uk (t.y). Local Government Act, 1974. 03.05 .2020 tarihinde https://www.legislation.gov.uk/ukpga/1974/7/contents adresinden erişilmiştir.

LGO. (t.y). Other organisations we can look at. https://www.lgo.org.uk/make-a-complaint/other-organisations-we-can-look-at adresinden erişilmiştir. 
LGO. (t.y). Our structure and staff. https://www.lgo.org.uk/information-centre/aboutus/who-we-are/our-structure adresinden erişilmiştir.

LGO. (t.y). Customer satisfaction research. https:/www.lgo.org.uk/informationcentre/about-us/our-performance/consultations-and-surveys/customer-satisfaction-research adresinden erişilmiştir.

LGO. (t.y). 2013-2014 annual report and accounts. https://www.lgo.org.uk/informationcentre/about-us/our performance/lgo-annual-reports adresinden erişilmiştir.

LGO. (t.y). 2014-2015 annual report and accounts https://www.lgo.org.uk/informationcentre/about-us/our-performance/lgo-annual-reports adresinden erişilmiştir.

LGO (t.y). 2016-2017 annual report and Accounts. https:/www.lgo.org.uk/informationcentre/about-us/our-performance/lgo-annual-reports adresinden erişilmiştir.

LGO (t.y). 2017-2018 annual report and accounts. https://www.lgo.org.uk/informationcentre/about-us/our-performance/lgo-annual-reports adresinden erişilmiştir.

LGO. (t.y) 2018-2019 annual report and accounts. https://www.lgo.org.uk/informationcentre/about-us/our-performance//go-annual-reports adresinden erişilmiştir.

LGO. (t.y). 2015-2016 customer satisfaction annual report. https://www.lgo.org.uk/information-centre/about-us/our-performance/consultations-and-surveys/customer-satisfaction-research adresinden erişilmiştir.

LGO. (t.y). 2016-2017 customer satisfaction annual report. https://www.lgo.org.uk/information-centre/about-us/our-performance/consultations-and-surveys/customer-satisfaction-research adresinden erişilmiştir.

LGO. (t.y) 2017-2018 customer satisfaction annual report. https:/www.lgo.org.uk/information-centre/about-us/our-performance/consultations-and-surveys/customersatisfaction-research adresinden erişilmiştir.

LGO. (t.y) Framework document, 2017. https://www.lgo.org.uk/assets/attach/2119/LGOFramework-Document-Dec-2017-new-logo.pdf adresinden erişilmiştir.

LGO. (t.y). Final complaint report, 2017. https://www.lgo.org.uk/information-centre/reports/annual-review-reports/local-government-complaint-reviews adresinden erişilmiştir.

Maer, L. ve Priddy, S. (2018), The parlaimentary ombudsman: Role and proposals for reform. Briefing Papers. https://commonslibrary.parliament.uk/research-briefings/cbp-7496/adresinden erişilmiştir.

Özden, K. (2010). Ombudsman Türkiye'deki tartışmalar. Seçkin Yayınevi, Ankara.

NHS. (t.y). About NFS. https://www.nhs.uk/using-the-nhs/about-the-nhs/how-to-complain-to-the-nhs/ adresinden erişilmiştir. 
Parliamentary Ombudsman of Finland. (t.y). International cooperation. https://www.oikeusasiamies.fi/en_GB/web/guest/the-institution-of-the-ombudsman-in-other-countries- adresinden erişilmiştir.

Parlaimentary and Health Service Ombudsman. (t.y). What to do before you come to us. https://www.ombudsman.org.uk/making-complaint/before-you-come-to-us adresinden erişilmiştir.

Parlak, B. ve Doğan, K. C. (2019). Kamu yönetiminde denetim ve ombudsmanlk dünya ve Türkiye uygulamaları. Ekin Basın Yayın Dağıtım, Bursa.

Sander, G. (2013). Ombudsman and local governments. International Local Governments Congress, 12-14 June, Venice, https://www.researchgate.net/publication/281283594 Ombudsman and Local Governments adresinden erişilmiştir.

Sezen, S. (2001). Ombudsman: Türkiye için nasıl bir çözüm? kamu denetçiliği kanun tasarısı üzerine bir değerlendirme. Amme İdaresi Dergisi, 4, 71-96.

Sobacı, M. Z. ve Özer, K. (2016). Ombudsman ve sosyal medya: kamu denetçiliği kurumunun twitter kullanımına yönelik ampirik bir analiz. Ankara Üniversitesi SBF Dergisi, 71(1),103-124.

Sandford, M. (2017). The local government ombudsman. Briefing Paper 17 July 2017. https://www.commonslibrary.parliament.uk/research-briefings/sn04117/ adresinden eerişilmiştir.

Usta, S. ve Akınc, A. (2016). Kamu yönetimindehesapverilebilirlik mekanizması olarak ombudsmanlık kurumu: Almanya örneği. Journal of Human Sciences, 13 (2), 2735-2750.

Uyanı, S. (1994). İngiliz yerel yönetimlerinde ombudsman denetimi. Türk İdare Dergisi, 403, 205-211.

Ünal, F. (2014). Türkiye'de yerel yönetimlerin denetimi ve yerel yönetim ombudsmanı. Savaş Yayınevi, Ankara.

Thomas, R. Martin, J.ve Kurkham, R. (2013). External evaluation of the local government ombudsman in England. https:/www.lgo.org.uk/assets/attach/2035/CLA-2008Evaluation-of-the-LGO-The-Final-Report-2-2-.pdf adresinden erişilmiştir.

\section{Kaynakça Bilgisi / Citation Information}

Erdoğan, M. (2021). İngiltere yerel yönetim ombudsmanlığının etkinliği üzerine bir değerlendirme. OPUS-Uluslararası Toplum Araştırmalarn Dergisi, 17(34), 1383-1407. DOI: 10.26466/opus.808839 